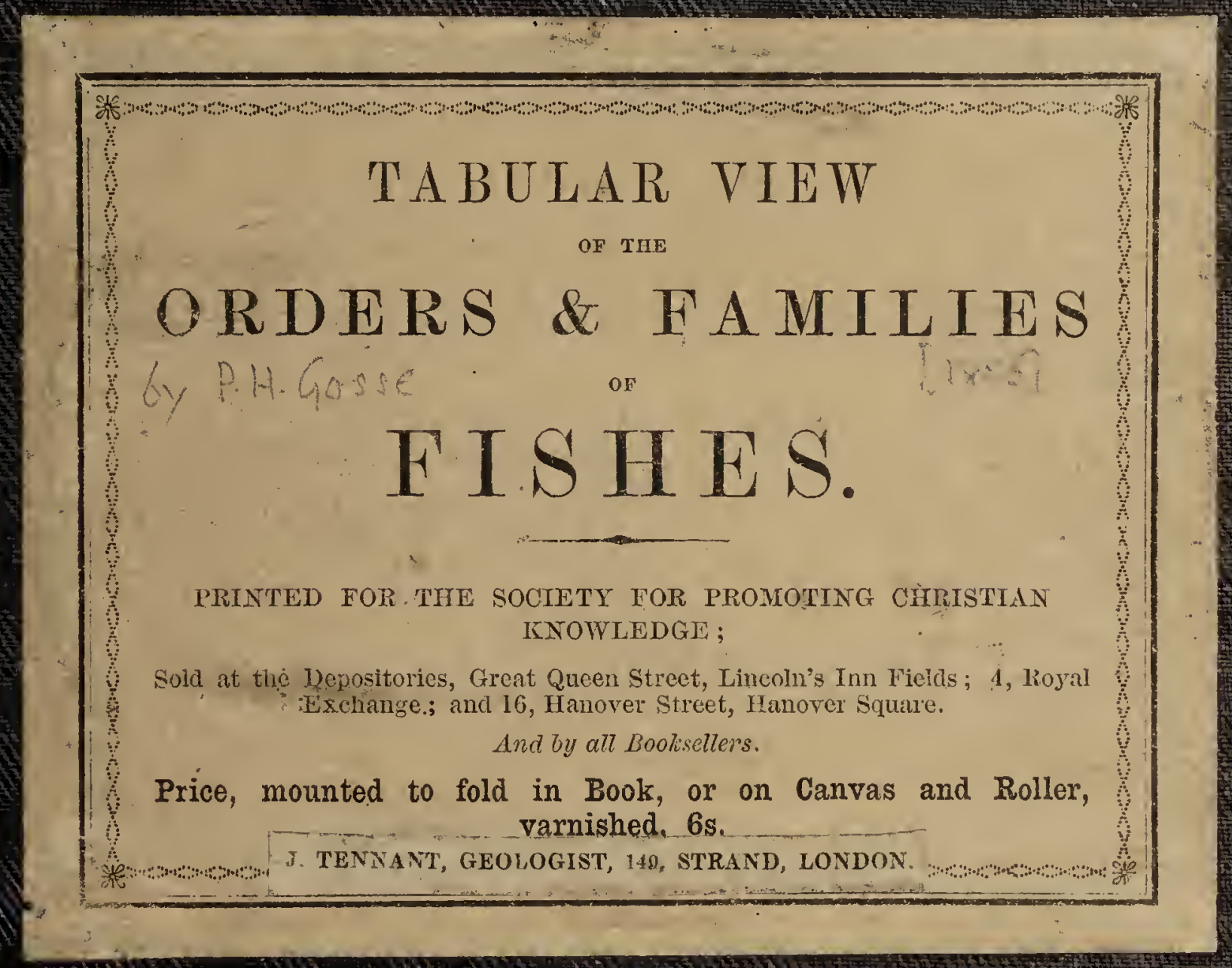




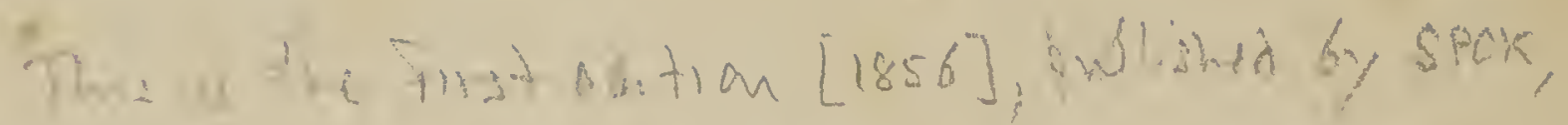

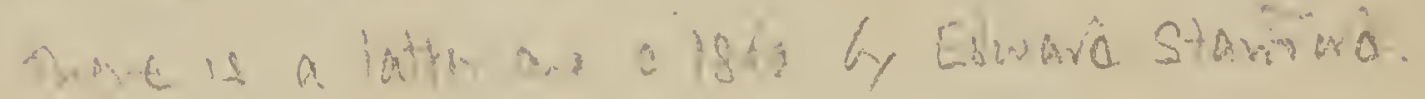
Inseydeds, onedatd riag 1857 PBB6/353

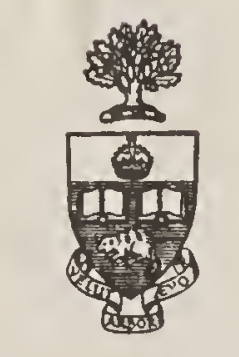

Library

of the

University of Toronto 



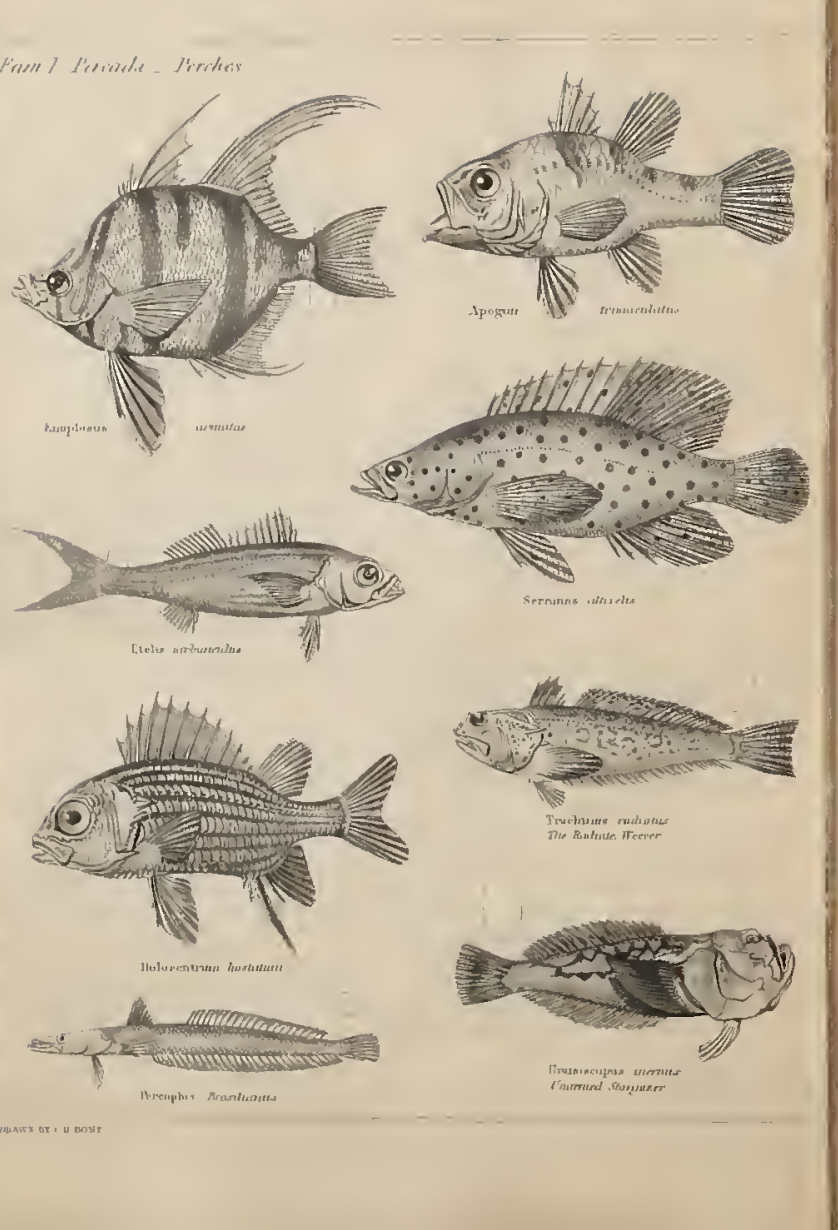

TABULAR VIIW OF THIT ORDIR S AND FAMILIES OF TISHES
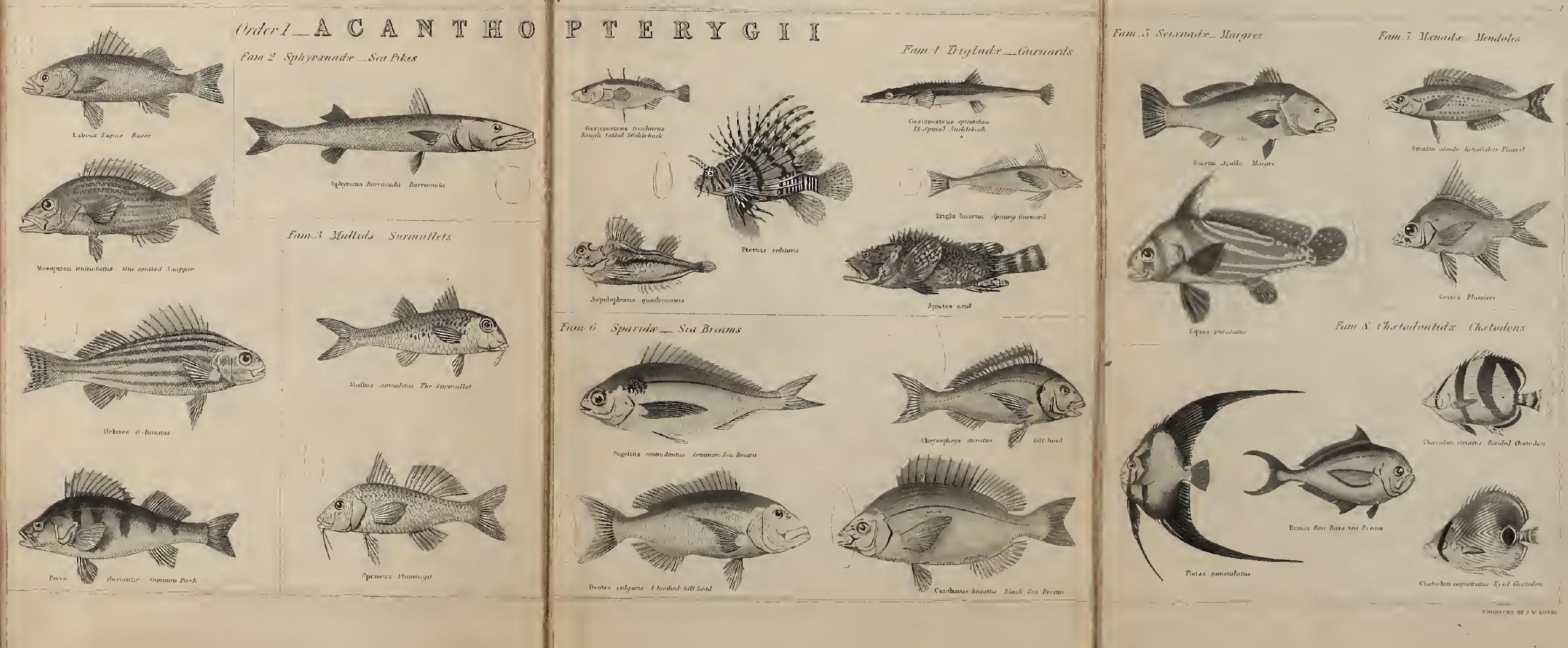
Digitized by the Internet Archive in 2018 with funding from University of Toronto 

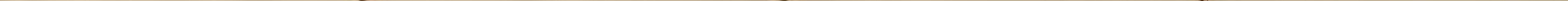



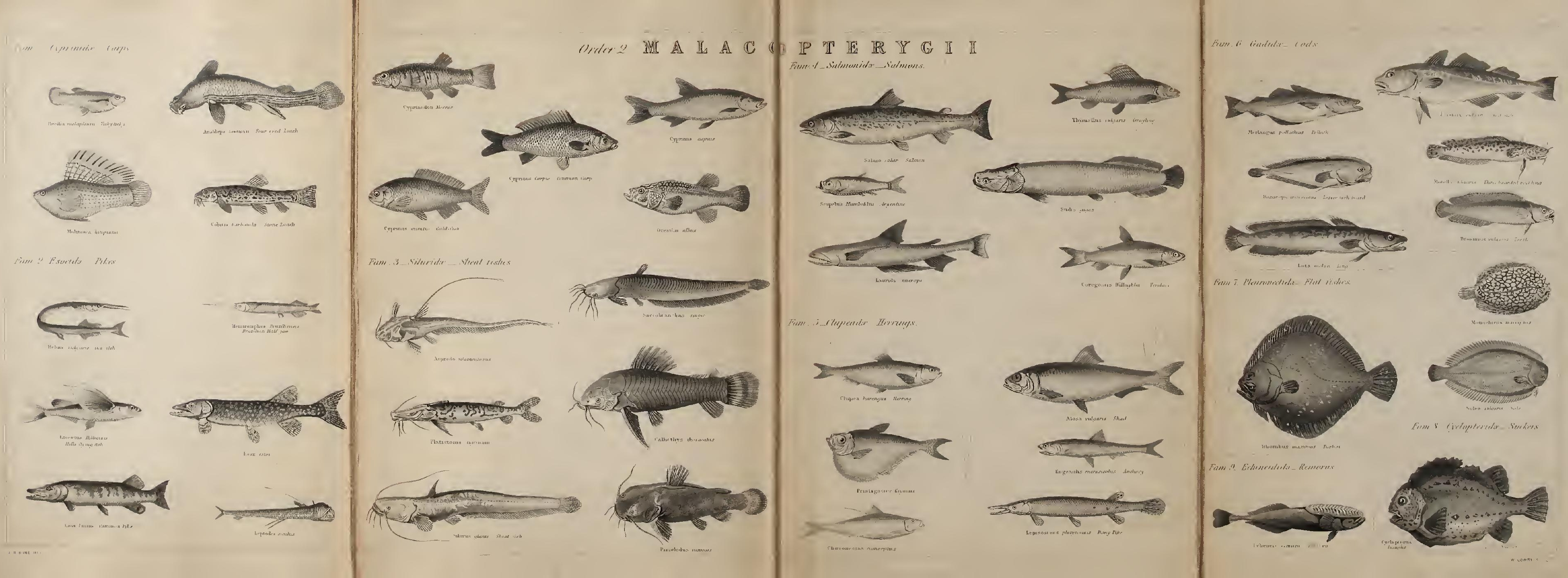




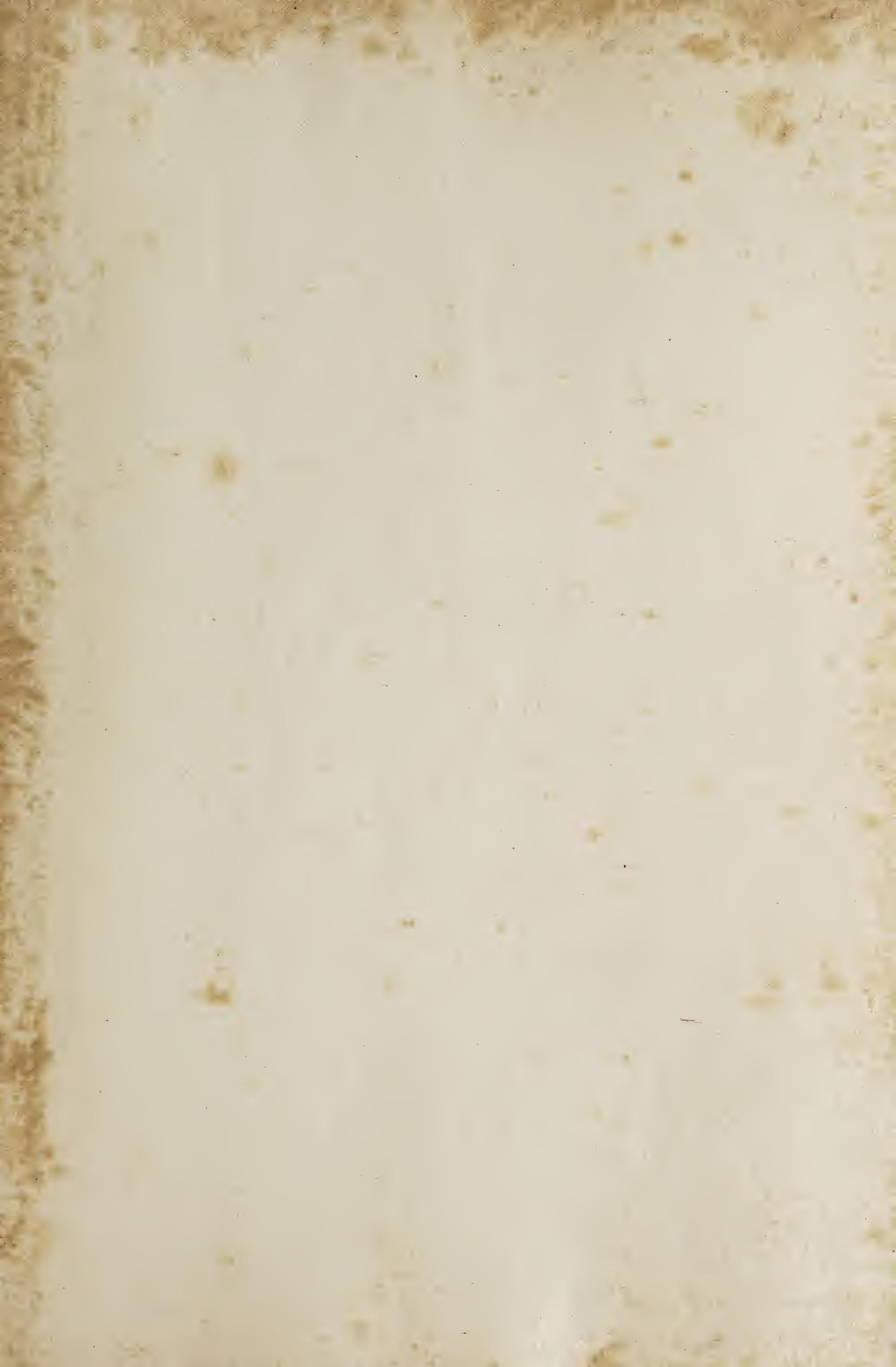




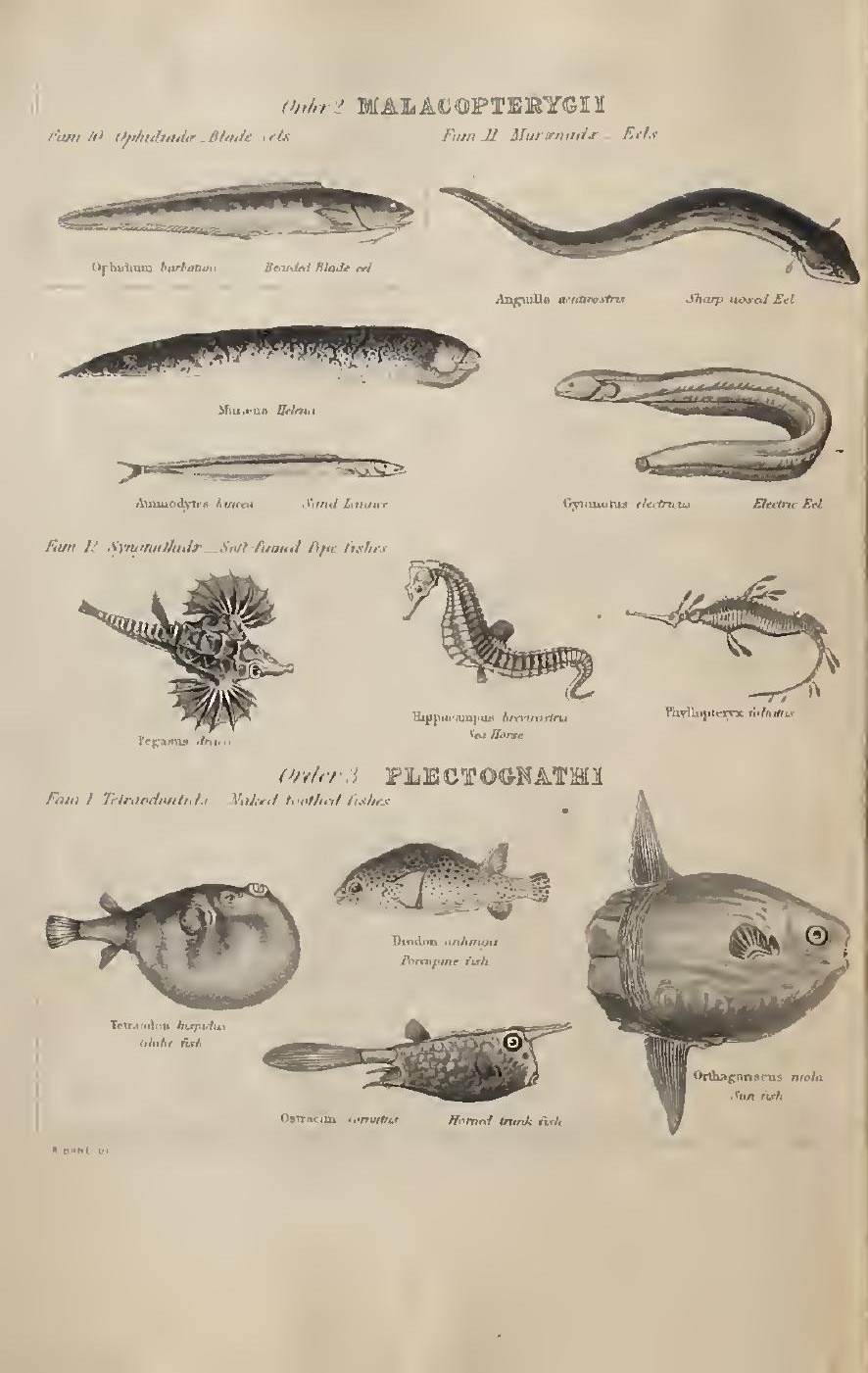

$$
\lim _{-1}
$$
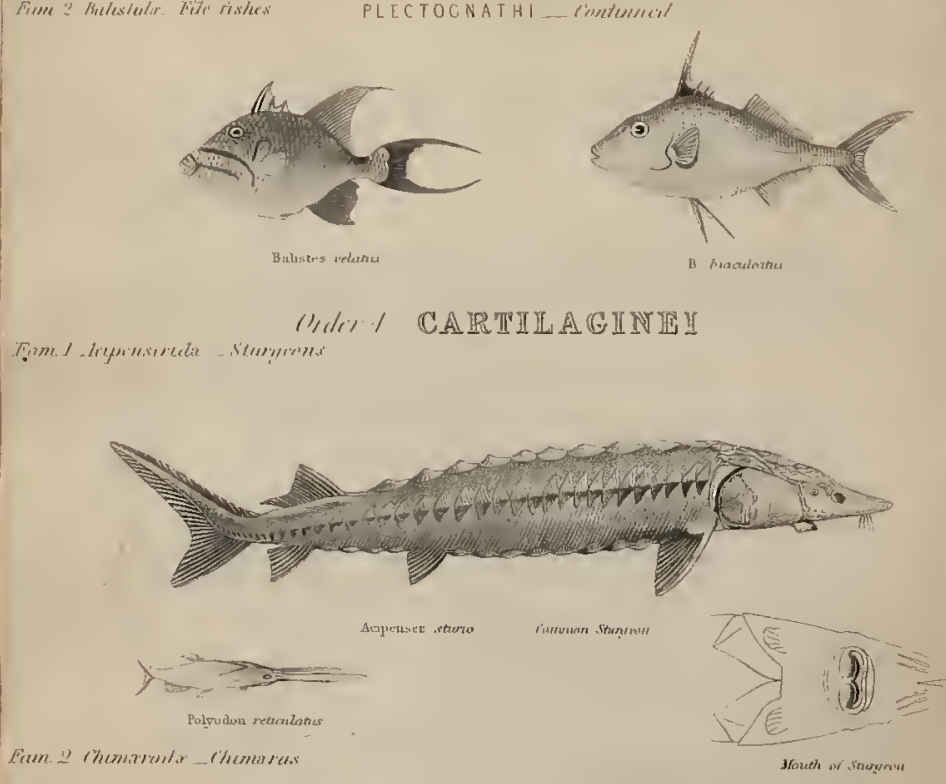

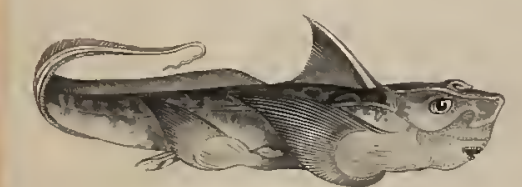

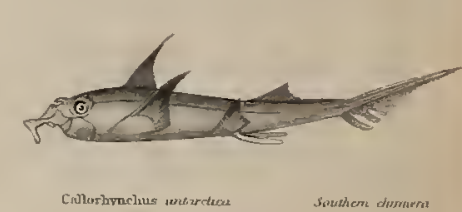

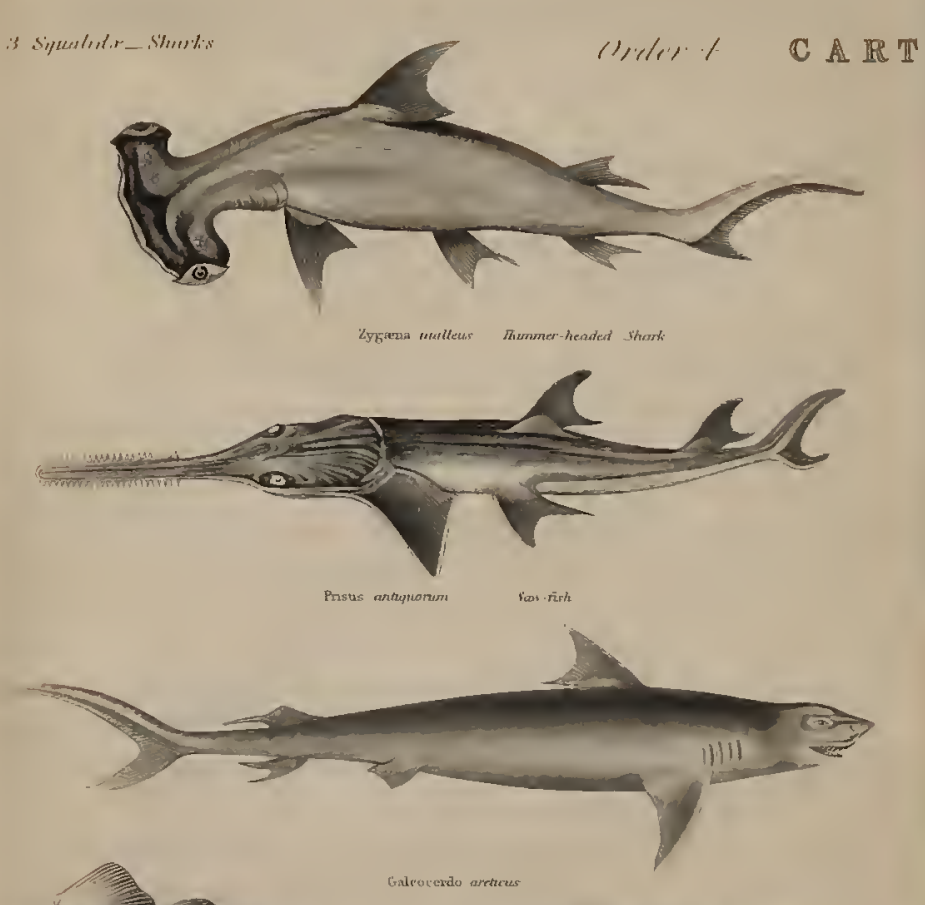

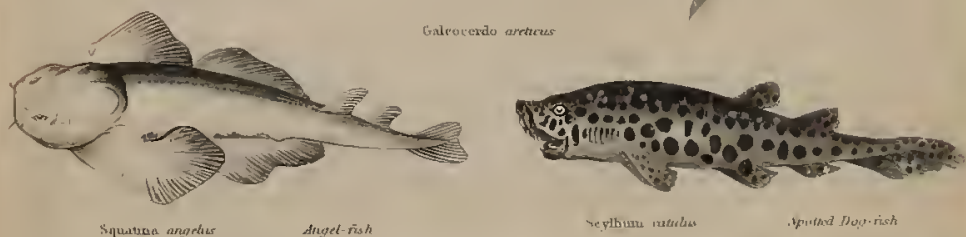

$\llbracket \mathbb{A} \mathbb{I} \mathbb{A} \mathbb{E}$
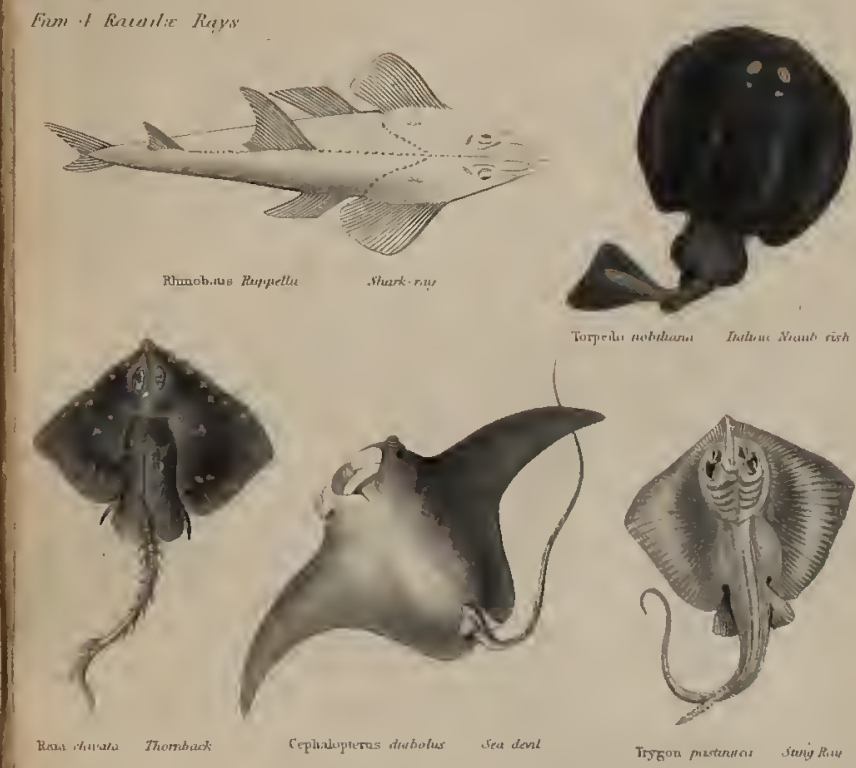

2n:

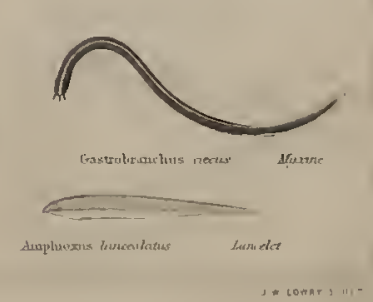




\section{BOOKS FOR THE COUNTRY.}

In fcap. 8vo, fancy cloth covers, with numerous Illustrations by the best Artists, Price One Shilling each (unless specified).

NEW VOLUME.

Price One Shilling, bound in boards,

\section{OUR WOODLANDS, HEATHS, AND HEDGES.}

(A COMPANION TO "WOOD'S COUNTRY OBJECTS.)

By W. S. COLEMAN.

ILLUSTRATED BY THEAUTHOR.

1. ANGLING;

CONTENTS OF THE SERIES :-

Or, How to Angle, and Where to Go. By Robert Blakex.

2. PIGEONS AND RABBITS.

Wild and Domesticated. By E. S. Delamer.

3. SHOOTING,

3. SHEEP.

In all its Varieties. By RoBerr Brakex.

Our Domestic Breeds, and their Treatment. By W. C. L. Martin.

5. FLAX AND HEMP.

Its Culture and Manipulation. By E. S. Defamer.

6. THE POULTRY YARD.

Including all its Varieties. By Miss E. Watrs.

7. THE PIG.

How to Choose, Breed, Feed, Cut-up, and Cure. By Marrin and Sidnex.

8. CATTLE.

Their History, Various Breeds, Management, Treatment, and Diseases. By Mantis, and W. and H. RAYNBIRD. Price 1s. $6 \mathrm{~d}$.

10. THE HORSE.

Its History, Management, and Treatment. By Youatr and CECiL.

11. BEES.

Their Habits, Management, and Treatment. By the Rer. J. G. Wood.

12. CAGE AND SINGING BIRDS.

How to Catch, Keep, Breed, and Rear. By H. G. ApaMs.

13. SMALL FARMS.

A Practical Treatise on their Management. By Martin Doyle.

14. THE KITCHEN GARDEN;

Or, Open-ground Culture of Roots, Vegetables, etc. By E. S. DefaMrer.

15. THE FLOWER GARDEN;

Or, Open-ground Culture of all Fluwers. By E. S. DetaMrr.

16. RURAL ECONOMY.

A Trensury of Infinmalion on the Hurse, Ponr, Mule, Ass, Cow-kikeping, Sheep, Pigs, Gual, Inoney-Bee, Punltry, etc. By Naitin Doxta.

17. FAR.M ANI) G.ARI)HN PR(O)C(CE

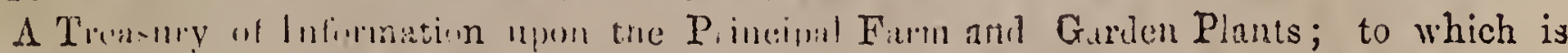

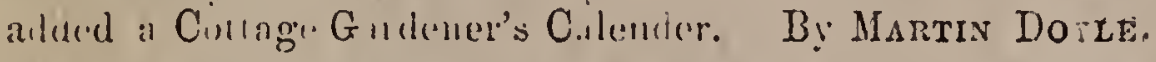

18. COMUON OBJEC'S OF THE SEA-SHORE.

Wirt Mints fin an Aquarium. by he Rev. J. G. Woud. With many Illustrations loy W. Sow r.bi:

19. COMMON OBJECTS OF THE COUNTRY.

By: the Rev. J. G. Wood. With many Illustrations by Culeman.

¿20. AGRICULIURAL CHEMISTRY.

(Price 1s. 6dl.) A Familiar Expianation of the Chemieal Princinles involved in Farn Operations. By A. Sibson, of the Royal Agricultural College, Cirencester; with a Preface by Dr. A. Vouluker. 


\section{POPULAR MIATURAL HISTORY. IMessrs. Routledge, Warnes, \& Routledge}

Have much pleasure in announcing that they have purchased from Mr. LOVELL REEVE his series of works on

\section{POPULAR \\ NATURAL \\ HISTORY,}

And in order to make them more generally known, they have published them, bound in cloth, at per volume,

\section{Seven Shillings aud Sixpence, coloured.}

1. British Birds' Eggs.

By R. Laishley. Twenty Plates. $7 s .6 d$. coloured, $5 s$. plain.

2. History of British Crustacea. By Adam Whire, F.L.S. Twenty Plates. 7s. $6 d$. coloured, 5 s. plain.

3. Popular Greenhouse Botany. By Agnes Catlow. Twenty Plates. 7s. $6 d$. coloured, $5 s$. plain.

4. Popular Field Botany.

By Aanes Catlow. Twenty Plates.

7s. $6 d$. coloured, $5 s$. plain.

5. Popular Geography of Plants. Edited by Dr. Daubeny. Twenty Plates. 7s. $6 d$. coloured, $5 s$. plain.

6. History of British Mosses.

By R. M. Stark. Twenty Plates. 7s. $6 d$. coloured, $5 s$. plain.

7. History of Palms.

By Dr. B. Seemans, F.L.S. Twenty Plates. 7s. $6 d$. coloured, $5 s$. plain.

8. History of British Seaweeds.

By Dr. Landsborougr. Twenty Plates.

$7 s .6 d$. coloured, $5 s$. plain.

9. Popular British Conchology.

By G. B. Sowerby, F.L.S. Twenty

Plates. $7 s .6 \%$ coloured, $5 s$. plain.

¿0. Popular British Ornithology:

By P. H. Gosse. Twenty Plates. $7 s .6 d$. coloured, $5 s$. plain.

1. History of the Mammalia.

By Aday White, F.L.S. Sixteen Plates.

7s. $6 d$. coloured, 5s. plain.

12. Popular Mineralogy.

By Henri Sowerux. Twenty Plates.

$7 s .6 \%$. coloured, $5 s$. plain.
13. History of the Aquarinm.

By G. B. Sowerny, F.L.S. Twenty

Plates. $7 s .6 d$. coloured, 5 s. plain.

14. History of Mollusca.

By Mary Roberts. Eighteen Plates.

7s. $6 d$. coloured, $5 s$. plain.

15. Popular Garden Botany.

By Agnes Citrow. Tiwenty Plates.

7s. 6d. coloured, 5s. plain.

16. Popular Economic Botany.

By T. C. Archer. Trenty Plates. $7 s .6 d$. coloured, $5 s$. plain.

17. History of British Ferns.

By T. Mloore, F.L.S. Twenty-two Plates. $7 s .6 d$. coloured, $5 s$. plain.

18. History of British Lichens.

By W: L. Lindsay, M.D. Twenty-two

Plates. 7s. 6 d. coloured, 5s, plain.

19. Popular Physical Geology.

By J. B. JukEs, F.R.S. Twenty Plates.

$7 s .6 d$. coloured, $5 s$. plain.

20. History of Zoophytes.

By Dr. Landsborovgr. 'Twenty Plates.

$7 s$. $6 \%$. coloured, $5 s$. plain.

21. Popular British Entomology.

By Maria E. Catlow. Sixteen Plates.

7s. $6 a$. coloured, $5 s$. plain.

22. Popular History of Birds.

By Adan White, F.L.S.S. Trenty Plates.

$7 s .6 d$. coloured, $5 s$. plain.

23. Popular Scripture Zoology.

By Maria E. Catiow. Sixteen Plates.

$7 s .6 d$. coloured, $5 s$. plain.

24. The Woodlands.

By Mart Roments. Twenty Plates:

7s. Gu. coloured, $5 s$. plain.

"A series published by Mr. Reeve, exceedingly well adapted for winning the sympathies and directing be observation towards natural objects." - Athenaum.

"A popular series of scientific treatises, which, from the simplicity of their style, and the artistic excel. ence and correctness of their numerous illustrations, has acquired a celebrity beyond that of any otber eries of modern cheap works." - Standard. 


\section{MESSRS. ROUTLEDGE, WARNES, AND ROUTLEDGE}

HAVE THE PLEASURE TO ANNOUNCE THAT THEY INTEND TO ISSUE,

IN FORTY-EIGHT SHILLING MONTHLY PARTS,

TMILAR IN SIZE AND APPEARATCE TO "ROUTLEDGE'S ILLUSTRATED SHAKSPEARE,

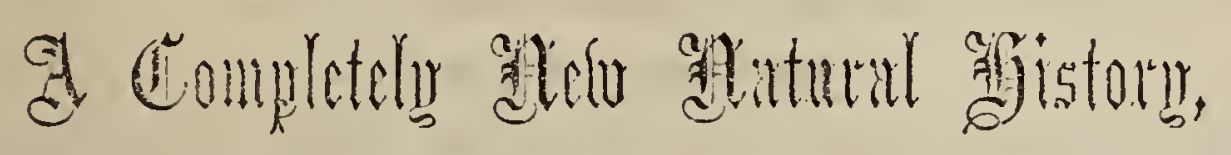

TO BE ENTITLED

\section{ROUTLEDGE'S}

\section{ILUTSTRATED

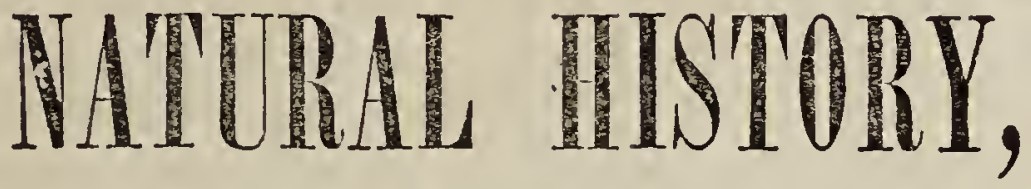

Dr THE

REV. J. G. W O O D, II.A., F.L.S., ETc.

ILLUSTRATED WITH DESIGNS BY

WOLF, HARVEY, HARRISON WEIR, COLEMAN, ETC., ETC. EXGRAVED BY DALZIEL BROTHERS.

Each Part will cuntain 48 pages of matter, printed in elcgant type, on fine paper, super roval sro, with the average number of thirty exquisite Trood Engravings.

Part I. will be ready for delivery on the 1st of April, 1859.

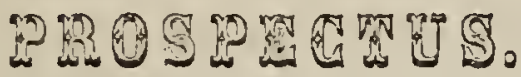

In consequence of the kind patronage that the Public have awarded to the "Illustrated Shalsspeare," the Publishers have determined to gratify the wish of numerous Correspondents, by issuing a comprehensive Natural History, treated in a Popular Style, with the view of supplying a want that has long been felt.

It is needless to cillarge upon the importance of a Work, undertaken upon this liberal scale on so delightful a branch of knorledge, which bocomes the more attractive the longer it is pursued. It is sufficient to say that the Imlustrated Natural History will embody all the leading facts with which the most eminent Naturalists have enriched the stores of this interesting science; and that the Illustrations will be designed by the best Artists of the presut day, pre-eminent for their skill in this branch.

\section{GENERAL FEATURES OF THE WORK.}

The original intention of the Author was to include the catire Animal Kingdom, from Mankind downwards. But the single subject of Man is so vast and so important that it would demand a much greater space than could be here afforded to it. With the exception, therefore, of a few allusions to the human form in comparison with the structure of various animal organizations, the description of Maukind will not be included in the present Work. 


\section{ROUTLEDGE'S ILLUSTRATED NATURAL HISTORY.}

This eomprehensive Work will eommonee with the Monkey Tribes, and descending through the seale of animated beings, will conclude with those curious creatures whose animal life is scarccly distinguishable from that of the vegetable. In the course of publication, several thousand Animals will be brought before the Reader, and he will be enabled, by reference to its pages to aseertain the relative position of any member of the Animal King.dom, and to form sonie idea of the part which it plays in the great drama of Nature.

\section{IN THE TEXT}

will be found a general outline of the Animal Kingdom, together with speeial accounts of its most important members. The chief charaeteristics that distinguish one order of Animals from another will be briefly noted, and in many instanees illustrative diagrams will accompany the descriptions.

It will be the endeavour of the Author to aroid as far as possible the erabbed and repcllent vocabulary that deters so many from the pursuit of that bcautiful study of Natural History, and to present to the Reader in simple language the many wondrous and varied forms in whieh Animal Life manifests itself. The seientific names of eaeh animal will necessarily bo retained in order to prevent the confusion which may be eaused by the exelusive use of the popular titles. But such terms will be explained, and their pronuneiation aceented.

The Author of the "Illustrated Natural History,'-The Rev. J. G. Wood, M.A., F.L.S.- has long been known to the public as the writer of "My Feathered Friends;" the "Common Objeets of the Country," and "Sea-shore;" "Sketches and Anecdotes of Animal Life;" and other volumes on Natural History. He has for some years past becn assiduously engaged in the preparation of the present Work, and sineercly trusts that the results of his labours will mect with the same lind reception from the Public as has been granted to his previous produetions.

\section{THE ILLUSTRATIONS.}

In order to render the subject of Natural History more intelligible to the Reader, this work will be copiously illustrated by the best qualifed Artists and Engravers. The names of WoLF, Weir, Harver, and Colenan are already so favourably known to the public as to render it unnecessary to makc any eomment here on their merits; while the reputation of the Brothers DuLziex as Engravers is a sufficicnt guarantee that their part of the task will be cxeeuted with the utmost skill and fidclity. Each Part will be embellished with the average number of

\section{THIRTY ELEGANT WOODCUTS.}

Wherever praeticable, the drawings will be made from the living animal, and in every instance the greatest pains talien to seeure aeeuraey of detail as well as pictorial effect.

The more important anatomical peculiarities of Animals will also be illustrated by Engrapings, and many examples will be given of the various struetures as seen through the mieroscope.

The Publishers, in thus announcing the plan of an undertaking in whieh they have eonfidently embarked an enormous outlay, and to the adequate carrying out of which they will derote their unremitting attention, have no hesitation in aflirming that their

\section{ILLUSTRATED NATURAL HISTORY}

will be unequalled for beauty of illustration, elegance of typographieal execution and paper, and lowness of price. For a sum which brings it within the reach of all the reading elasses, the Publishcrs offer to the Public the only Work yet written in a style at once popular and seientifie, which embraces the entire Animal Kingdom, and is illustrated in a manner worthy of the subjeet.

They spceially reeommend this Work to Sehools, Public Libraries, Mechanics' Institutes and Families generally, to whose bookshelves its handsome appearance will make it an ornament, while its low priee will render it easy of attainment.

specimen of the Work, with the Woodcuts, may be had Gratis on application to the Publishors.

London: Routledge, Warnes, \& Routledge, Farringdon Street. 


\section{HALF HOURS WITH THE BEST AUTHORS.}

In Sixpenny Fortnightly Parts.

On the First of March will be ready, PART I., price SIxPExce

OF

\section{HALF HOURS WITH THE BEST AUTHORS,}

\section{SELECTED AND EDITED \\ BY CHARLES KNIGHT.}

WITH SHORT BIOGRAPHICAL AND CRITICAL NOTICES.

This Work will be completed in Twenty Sixpenny Parts, and will be embcllished with steel portraits of sixteen of the most celebrated authors, and fifty-two wood engravings by William Harvey.

Each part will contain fourteen pieccs of a sufficient length to occupy half an hour's ordinary reading; two of the subjects, the seventh and fourteenth in each part, will be sclected from some theological writer of universal acceptance and authority.

The complete work, forming a Circle of English Literature, comprises Imaginativc, Dc. scriptive, and Dramatic Verse; Remarkable Adventurcs; Moral and Religious Exhortationtaken from the best works-gems from the rich treasury of instruction and amusement, of which the master minds of the world, and especially of our nation, have laid up an exhaustless and impcrishable store.

\section{Part I., price 6d., with Steel Plate and Two Illustrations,}

WILL COMIPRISE THE FOLLOWIYG:-

NFLUENCE OF SCIENCE, by Sir JOHN HERSCHEL.

DEATH OF THE SON OF GASTON

DE FOIX, by FroIsSART.

SCENES FROM "THE CITY MADAM" by MASSINGER.

THE SACK OF MAGDEBURG, by HARTE.

A TALE OF TERROR, by CoURIER.

THE OPENING YEAR, by the Poets.

A GOOD MAN'S DAY, by Bishop HaIL.
ROGER ASCHAM AND LADY JANE GREY, by LANDER.

ON DEJECTION, by COLERIDGE. APOTHEGMS, by Various Author's.

SPEECH AT PLYMOUTH, by GEORGE CANNING.

SIR ROGER DE COVERLEY, by ADDISON.

THE BAROMETER, by ARNotT. SUNDAY, by GEORGE HERBERT.

The Complete Work in Four Vols., rprice 14s., or bound in Two, price 12s., may be now obtained of the Publishers.

London: Routledge, Warnes, \& Routledge, Farringdon Street. 


\section{In Sixpenny Fortnightly Parts.}

On the lst of March will be ready, Part I., with Twenty Illustrations, price Sixpence, of

\section{BOSWELL'S LIFE OF JOHNSON:}

TO BE COMPLETED IN TWENTY-TWO PARTS;

COMPREHENDING

An Account of his Studies and numerous Works, in chronological order, and his Correspondence and Conversations with many eminent Persons: the whole exhibiting a most accurate and entertaining sketch of the state of Literature, with a vivid portraiture of its brightest ornaments, in Great Britain, during the period in which he flourished, extending over nearly half a century.

Illustrated with mumerous Portraits, Views, and Characteristic Designs, Engraved from authentic sources.

\section{EXTRACT FROM THE PREFACE.}

"A work so well known as 'BosweriL's Life of Johnson,' needs no eulogy to those who have read it. Hitherto, however, the book has hardly been brought within reach of the great mass of the lovers of literature; and it may interest those who make acquaintance for the first time with this masterpiece of Biography, to know that the most eminent of critics who have written upon the subject since the book first appeared, are unanimous in their opinion, that as a life-like portraiture, not only of the personal appearance and singular habits of a distinguished man, but of his strong prejudices, his vigorous eloquence, his homely common sense, and his ready wit, so strikingly shown in the series of conversations which the industry of Boswell has preserved to us-this book stands unrivalled in the literature of our own or any other nation. It is to be hoped that the present edition will recommend itself, both by its cheapness and by the more sterling qualities of careful annotation and copious and judicious illustration which it will be found to possess, to many thousands of readers who have not hitherto had an opportunity of becoming familiar with the work."

The Work, complete in Four Vols., price 10s., or bound in Two, price 10s., may be now obtained of the Publishers.

\section{Iondon: Routledge, Warnes, \& Routledge, Farringdon Street.}

Thomas Harridl, Printer, Salisbury Square, Fleet Street, London. 


\title{
ABSTRACT OF A LECTURE ON
}

\section{MINERALOGY, \& ITS APPLICATION TO GEOLOGY \& THE ARTS,}

\author{
Given at St. Martin's Hall, Long Acre, August 4, 1854, in connection with the
}

\begin{abstract}
EDUCATIONAI EXHIBITION OF THESOCIETY OF ARTS,
\end{abstract}
BY PROFESSOR J. TENNANT, F.G.S.

(Reprinted from the "Journal of the Society of Arts," No. 92, Vol. II., page 680.)

The lecturer commeneed by ealling attention to the / which in iron, coal, lead, limestone, and sandstone yielded eoncluding portion of his lecture before the Society of Arts, being one of the series delivered on the results of the Great Exhibition of 1851 .

The leeturer said it was desirable " to draw the attention of all persons likely to travel in foreign eountries, especially to Australia, Cape of Good IIope, India, and Canada, to the great importance of a linowledge of minerals. There is no eountry in the world possessing a wider range of territory or greater mineral wealth than Great Britain ; consequently, there is none in whieh the study of mineralogy is more important; yet the ignorance which prevails on the subject is astonishing. I am frequently receiving paekages and letters of inquiry from. our eolonies, containing pebbles of quartz and bits of shining iron pyrites, which a few simple expcriments would render unnecessary. A very sinall amount of linowledge as to the method of testing minerals, espeeially as to their spceifie gravity, would save months of anxious suspense, which must oecur while waiting a reply from England. But I am not without hope that the ignorance which leads to sueh mistakes as these will gradually be dispelled."-Tecture on Gems and Precious Stones, delivered at the Society of Arts, March 24, 1852.*

Members of the Society, by applying for it, might have had a eopy of the above leeture referred to, but Mr. Temnant believed upwards of 400 eopies were still remaining on the shelves of the Society. Sinee then the strects of London have been placarded with large papers; first ad vertising the John Bull "Gold Nugget" from the Vietoria diggings, weighing $45 \mathrm{lbs}$. 6oz. 'I'his yielded gold to the valne of $£ 2,500$. Secondly, a pieee of gold quartz arrived by the "Sarah Sands" from Ballarat, Australia, weighing 1341bs. 11oz., whieh was denominated the "Monster Nugget," and was exhibited for some time at the Globe in Leieester Square. Mr. Tennant said he was present at the melting of this piece in July, 1853; it yiclded $£ 5,5327$ s. 4 d. worth of gold, and was the largest yet received. We arc informed by the publie paper's that grold in California has been found in value exeecding 45 million pounds sterling. From our own colonies immense quantitics have been reeeived; the exact amount it would be difficult to ascertain. He was informed, by competent persons, that it exeeded twenty millions sterling within three years. When conversing with those who had returned successful in gold eolleeting from our eolonies, he found them unaequainted with the ores of silver, eopper, tin, mercury, lead, antimony, bismuth, all preeious stones, and many ether minerals of considerable value, not only in a eommercial point of view, but as a means of relieving the wants of the emigrant anxious to establish himself in a new eountry. Mr. 'Tennant doubted whether gold was the only metal worth searehing for, and instanced the carboniferous formation of England,

* The public can obtain a copy of the lecture for twopence, by purcliasing Nos. 94 and 95 of the " Tome Friend," a weekly penny publication, issued by the Society for Promoting Christian Kinowledge. more than twenty millions sterling annually. These few remarks would show the importance of the study of mineralogy as a branch of natnral history, but yet it is very much neglected in England.

The lecturer then proeceded to enumcrate the attempts which have been made in the present eentury to establish schools for mining. In 1804 Sir John St. Aubyn, Sir Abraham Hume, and the Right Honourable C. F. Greville, each possessed very extensive cullections of mincrals That formed by Sir John St. Aubyn is now in the Mu. seum at Devonport, and is rich in metallic minerals; that by Sir A. Hume, which contained many gems, was presented by Lord Alford to the Muscum at Cambridge; the Hon. Mr. Greville's collection was bought by the trustees of the British Museum, and is rich in earbonates of linc. These gentlemen endeavoured to raise $£ 4,000$ for forming at the Royal Institution a scientific colleetion of minarals, under the arrangement of a good mineralogist, and of establishing an additional laboratory there under the direction of an eminent chemist, to be exclusively employed on the assay of metals, and for the advaneement of minerals and metallurgy. At that time the Royal Institution had the best public collection in London. It had been formed by Davy in 1803, and been added to by Hatehett, Cavendish, Wollaston, Brande, and others. University College and King's College were established abont 1831. The former has had the able assistanee of Messis. Phillips, Webster, and Morris; the latter of Sir Charies Lyell, Phillips, and Ansted. Mrr. Tennant was appointed leeturer on mineralogy in 183s, and suceceded Mr. Ansted in geology in 1853. King's College possesses a good colleetion of minerals and rocks, exeeeding 2,500 specimens, which are accessible to the students.

In 1838, Sir Charles Lemon made a most liberal offer of $£ 10,000$ towards establishing a mining school at Truro, in Cornwall, on certain conditions, whieh it is to be regretted wcre not carried out. Some very interesting particulars of this noble offer are to be found in the Rev. II. Moseley's Reports on Elementary Sehools, in the Minutes of the Committec of Council on Edueation, 1851-52. (Vide p. 13.) Parties are again trying to form an Elementary Mining Sehool in Cornwall, and it is to be hoped they will succeed. If all those interested in mining considered the amount of capital lost in fruitless attempts to work mines, they would find it to their pecuniary interest to establish schools in all our mining districts. The engineer and agricnlturist might, with our inproved mode of transit by railway, introdnce superior materials for eonstrueting buildings and improving soils.

In 1851 Sir Hemry De la Beehe sueeeeded in opening the Muscum of Practical Geology, and engaging some of the most eminent men as teachers. 'The eollection comprises minerals, sneh as iron, coal, lead, eopper, tin, salt, roofing slate, granite for paving our streets, limestone for eonstrueting our buildings, clay for bricks and pottery, sand for glass, \&c., \&c. 'The obtaining of all these matcrials gives employment to a very large proportion of our popu- 
2

lation, and their value is upwards of thirty-six million sterling per annum.

The lecturer exhibited diagrams of the minerals entering into the composition of metamorphic and volcanic rocks, also those confined more particularly to sedimentary rocks. He pointed out a few instances of the easy method of distinguishing the most common. Thus, on the sides of rivers rounded pebbles of quartz and calcareous spar are frequently to be picked up, exhibiting no crystalline form. If quartz, it will not yield to the knife, and when broken exhibits a curved fracture like a piecc of broken glass (see fig. 1). Calcareous spar, on the contrary, when broken, exhibits a rhomboidal form (see fig. 2). The

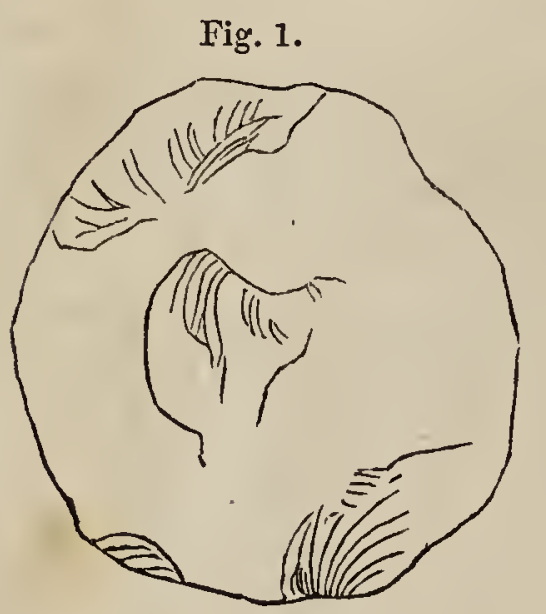

Fig. 2.

faces and angles are as smooth as though they had been polished by the lapidary. Calcareous spar is readily scratched by the knife, and is aeted upon by an acid. In this way a student will acquire more information in a dozen or twenty lessons from a teacher who will select a number of minerals having some characters in common, such as schorl and oxide of tin ; copper, or iron pyrites, and gold; heavy spar, and calcareous spar; cinnabar, and some varieties of oxide of iron; ar'senical iron, and platina; than by reading volumes on geology. He stated that several instances of serious mistakes had come beforc him within the last few years, in which one mineral har been substitnted for the otler in commercial transactions.

'To those who have an opportunity of studying our national collection of minerals in the British Museum, which is probably the finest in the world, having cost the government upwards of $£ 30,000$ independent of many valuable gifts from the Rev. Mr. Cracherode and other's, the followiug remarks may be found useful:-The Museum is open Mondays, Wednesdays, and Fridays, also on Tuesdays and Thursdays for students, who have little difficulty in gaining access. First purchase a Synopsis, the price of which is only twopence ; then, by referring to the index, the case contajning particular specimens may be readily found. The collection is arranged in sixty cases, according to the chemical system of Berzelius; the names of the minerals are printed on labels with borders coloured either red, green, blue, or yellow; a thin slip of wood of the same colour surrounds all the varieties of that species. This is particularly necessaly to be observed, becausc of some species therc are many varieties, in otlers probably only one or two spccimens. A small written paper accompanics many specimens, giving the locality. By occasional visits of this kind and a good work on Miueralogy much information may be gained. The lecturer contrasted the present facilities afforded to the student with those of tifty year's since, and refcrred to Professor Silliman's late visit to England. Another mode of obtaining a practical knowledge of milleralogy aud geology is to visit the mountainous districts of the British Isles; and although not having the high mountains of Switzerland and other countries, the British Isles will yield to none in intcrest. Hc had frequently seen the students of Germany travelling in companies, and always rccommended the same plan to his own students in the summer vacation, as it brought them back to attend the approaching year's lectures with additional interest, and often induced the careless young man to become one of the most diligent.

At KING'S COLLEGE, London, Lectures on Mineralogy are given on Wednesday and Friday Mornings, from Nine to Ten o'clock, from October to Christmas, to which the public are admitted on paying the College Fees.

\section{MINERALOGY.}

The Course commences with a description of the Physical and Chemical characters of Minerals in general.

The principal simple Minerals are next scparatcly considered, and the readiest mode of distinguishing them described.

The course of instruction inclndes a minute description of all the substances entering into the composition of Rocks, and of those minerals which are also used in the Arts; illustrated by an extensive collection of characteristic specimens, and diagrams of the principal crystalline forms, \&c.

Mr. TENNANT gives privatc instruction in Mineralogy and Geology at his residence, No. 149, Strand, London. He can supply Elementary Collections at 2, 5, 10, 20, 50, to 100 guineas each, and every requisite to assist those commencing the study of these intercsting branches of Science, a knowledge of which affords so much pleasure to the traveller in all parts of the world.

A collection for Five Guineas, which will illustrate the recent works on Gcology, by Lyell, Mantell, and others. contains 200 specimens, in a plain Mahogany Cabinet, with five trays, comprising the following specimens, viz.:-

Minerals which are eithcr the components of Rocks, or occasionally embedded in them :-Quartz, Agate, Chalcedony, Jasper, Garnet, Zeolite, Hornblende, Augite, Asbestus, Felspar, Mica, Talc, Tourmalinc, Calcareous Spar, Fluor, Selenite, Baryta, Strontia, Salt, Sulphur, Plumbago, Bitumen, \&c.

Native Metals, or Metalliferous Mrnerals; these are found in inasses or beds, in veins, and occasionally in the beds of rivers. Specimens of the following Mctallic Ores are put in the Cabinet:-Iron, Manganese, Lcad, Tin, Zinc, Copper, Antimony, Silver, Gold, Platina, \&c.

Rocrs; Granite, Gneiss, Mica-slate, Clay-slate, Porphyry, Scrpentine, Sandstones, Limestones, Basalt, Lavas, \&c.

Palaeozorc Fossils, from the Llandeilo, Wenlock, Ludlow, Devonian, and Carboniferous Rocks.

Secondary, Fossils, from the Lias, Oolite, Wealden, and Cretaceous Groups.

Tertiary Fossils, from the Plastic-clay, London-Clay, Crag, \&

In the more expensive collections some of the specimens are rare, and all more select. Mr. Tennant bought at the Stowe sale the Duke of Buckingham's collection; for this he asks 1000 guincas. It contains upwards of 3000 specimens, many of which are of great interest. Hc has refused $£ 25$ for one specimen and $£ 30$ for another. 
On the 1 st of July, ParT I. of

\title{
BRITISH WILD FLOWERS.
}

\author{
I L L U S T R A T E D
}

\author{
BY \\ JOHN E. SOWERBY, \\ ILLUSTRATOR OF THE FERNS OF GREAT BRITAIN, \\ THE GRASSES OF GREAT BRITAIN, ETC.
}

\section{E S C R I B E D,}

WITH AN INTRODUCTION AND A KEY TO THE NATURAL ORDERS,

BY

C. PIERPOINT JOHNSON.

As illustrated Manual of British Botany has long been a desideratum. While the few works hitherto published containing coloured figures of all the English Wild Flowers are far too voluminous for use in the fields and woods, and too costly to be within the reach of many, the excellent books of Hooker, Lindley and Babington, however well adapted for the professed student of botany, are too technical and elaborate for the purpose of the beginner.

Botany, notwithstanding the popular dogma, is not a "science of hard names." It is the study of the habits and adaptations of the most beautiful of the inanimate works of the Creator-a study that can be pursued with profit only in the open air-on mountain, woodland, marsh and hedge-bank-not by turning over the musty leaves and discoloured straw of an herbarium, or poring over the crabbed technicalities and latinized phraseology which have repelled so many from the threshold of Science.

The present work, while furnishing, it is hoped, a useful fieldbook for the reference of the student of British Botany, will at the 
same time enable the less scientific observer to distinguish at a glance the species of any flowering plant found growing wild in our islands.

It will contain carefully coloured figures of every British flowering plant, drawn upon a reduced scale from Sowerby's English Botany, including those published in the three volumes of Supplement to that work. The specific descriptions will necessarily be concise, but will be rendered as clear and intelligible as possible, while for the assistance of the student references will be given to the more elaborate works above mentioned. A short introduction to the Natural Orders and Genera will be added, with a glossary of botanical terms.

\section{The book will comprise eighty plates, each containing twenty figures, forming, with the letter-press, a complete illustrated Manual of the British Flora.}

\section{Part I. will be ready on the Ist of July.}

\section{PROSPECTUS.}

The work will be completed in Twenty Parts, Monthly, each Part to contain Four Plates of Twenty Figures each and their descriptions.

Coloured, 3s. per Part.

Plain, 1s. 6d. per Part.

The Introduction, Key, and Glossary will appear in portions at intervals of two or three months.

The Colouring having to be done by hand, it is desirable that Subscribers' names for the Coloured Copies be sent to the Publisher as early as possible, in order that a sufficient supply be prepared.

To be had through all Booksellers, or of the Publisher,

JOHN E. SOWERBY, 3 MEAD PLACE, LAMBETH. S. 


\title{
ON VISUAL EDUCATION AS APPLIED TO GEOLOGY.
}

ILLUSTRATED BY

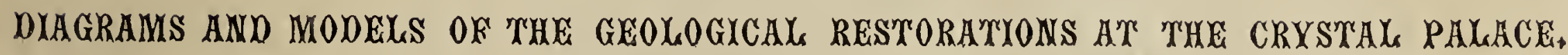

\author{
Read before the Society of Arts,
}

\section{BY B. WATERHOUSE HAWKINS, F.G.S., F.I.S., May 17, 1854,}

And reprinted from the Journal of the Society of Arts, No. 78.

It has been truly said, that the highest function of the Society of Arts must be its endeavour to promote the general advancement of education; and in the belief that such are the praetical views of this Society, I presume, that its members cannot view with indifferenee any par't of that great undertaking at the Crystal Palace, which may be so justly called a grand-child of the Soeiety of Arts. It was here that the Great Exhibition of 1851 first saw the light, and which, under the happy auspices of our Royal President, was brought to maturity - a giant, born of peace and good-will to men; of such parentage how much is to be hoped for!

In this the 100th year of our existence as a Society, it is most happily eoneeived to lay before the whole world an exhibition of all the materials of education collected from all nations; therefore, in the hope that you will consider my attempt at least seasonable, I shall endeavour, very briefly, to lay before you this evening a slight sketch of part of one of those great efforts in an educational direction which the Crystal Palace Cornpany are making for the benefit of their fellow-men of all classes; and no less is it a benefit to their fellow-men because it is being done commercially, which, if properly analysed, will be found to be the most truly independent system and most congenial to the feeling of every right-minded Englishman.

'The whole of the great scheme now working to completion, known as the Crystal Palace, might be properly described as one vast and combined experiment of visual education; and I think it would be easy to show that its educational powers and design constitute its legitimate claims to the support of all civilised Europe; but like its great parent, the Exhibition of $180 \tilde{1}$, it is too extensive to allow of even a short catalogue in the brief space of one hour ; I therefore confine myself to a hasty sketch of part of the attempt to apply the active principle of teaching directly through the eye that branch of the truths of creation upon which I have been engaged for the last year and half.

'This direct teaching through the eye his been recognised as a principle and a facility of education for some years past, even in the limited sphere of schools; and I believe the name of Pestalozzi deserves the most honourable mention in connection with its first enunciation as a recognised faeility upon principlc. His, and his followers' lessons on objects were niged upon the public some twenty years ago, and a writer who was quoted at the time, in support of the principle, shrewdly observed, that " we daily call a great many things by their names, without even inquiring into their nature and properties, so that in reality it is only their names, and not the things themselves, with which we are acquainted." If this remark be so applicable to our superficial knowledge of every-day objects, how much more literally true does it become when applied to that branch of science and truth (for science is only a synonyme for truth) which the Crystal Palace Company have so boldly undertaken to lay before the multitude; there we shall reverse that order of teaching which is described as the names and not the thing:s with which we become acquainted; it will be the things with their names that we shall present to the people; and not only the people in the restricted sense of the word, but to the million, including the well-informed and those above the average in edncation and acquirements; to the majority, these geological restorations will present all the novelty of a first aequaintance, for, with reference to the true form and size of the extinct animals, little more than the name was known to many who had an earnest desire to acquire some knowledge of geology, but whose scanty leisure would not allow of their pursuing their inquiries sufficiently fal to realize that life-like interest which becomes almost essential for the successful continuance of any pursuit. Our natural sympathies are with life. That which does or has lived will always be found to interest far beyond any inorganic object, however brilliant or beautiful.

Of course it is not my intention to offer you on the present occasion a lecture on Geology, or Palreontology, but only simply to describe in a few words the foundation upon which I have constructed and restored these great animals, and how I have obtained that truth and accuracy which may entitle my restorations of the extinct animals to be viewed as useful and trustworthy lessons to all classes, and which we hope will render the appearance and names of the ancient inhabitants of our globe as familiar as household words.

Geology and Palæontology, though deeply interesting to all who have had the opportunity for study, have hitherto been restricted to the professed anatomist, or to those whose great resources enabled them to make collections and to bring around them the costly requisites of their enthusiastically followed pursuit. Sir Philip Egerton, Lord Emniskillen, Sir Roderick Murchison, Dr. Mantell, Mrr. Bowerbank, and other distinguished names illustrate the limited number to whom the study of Geology and $\mathrm{Pa}$ laontology was practically within reach. We have public museums, it is true, but even our national collection at the British Museum, though containing some of the finest fossils that have been collected throughout the world, from their detached state, there being only two or three skeletons for comparison, offers little more than objects of wonder, literally only dry bones, or oddly-shaped stones, to the majority who see them. The inevitably fragmentary state of such specimens of course left much to the imagination, even to those who looked at them with some little knowledge of comparative anatomy, and, as that amount of knowledge is not found among the average acquirements of the public at large, it was a fallow field, which nothing less than the great enterprise and resources of the Crystal Palace Company could have attempted for the first time to illustrate and realise-the revivifying of the ancient world-to call up from the abyss of time and from the depth of the earth those vast forms and gigantic beasts which the Almighty Creator designed with fitness to inhabit and precede us in possession of this part of the earth called Great Britain.

Geology has been aptly called the science of nature's antiquities, for, however fresh, renewed, and vigorous in all her operations, yet even nature has had her olden time; her early days must have seen fierce strulggles, contentious storms, fire and water, like the modem theories, struggling for the mastery; then her epoch of calmer subsistence and gentler rule, each state leaving its indestructible monuments, with their carvings and inscriptions, for man to decypher. Nature's pyramids are mountains of granite, slate, and limestone; her aqueducts majesticrivers, leaving gigantic boulders for land-marks; but more to our immediate purpose, the geologist, like the modern antiquarian, finds his richest stores of information in nature's cemeteries, where the bones of bygone generations lio embalmed with proofs of how they lived and where they died.

The science of Palæontology (or', as the literal transla- 
tion of the name indicates, the study of aneient beings) treats of the history of fossils; and its principal end is to make known the forms and the zoological relations of the beings which have inhabited the globe at divers epochs anterior to our own. It has also to fill one of the most remarkable pages in the history of the earth. by retracing the successive phases of the organization of the animals that have peopled it. It has two principal applications :1st to Zoology, by making known those new or rather unlinown forms and conditions of existence which are often wanting in living' nature. It may, sometimes, by offering new transitions, demonstrate natural relations of which we were ignorant; it reacts also upon the general laws of comparative anatomy, and has contributed much to its researches and discoveries, and it is conneeted with all the questions relative to the origin and development of organised beings. 2ndly to Geology :-Palæontology again supplies geology with the only certain basis for the determination of the stratified rocks, and by clearing up several essential points relative to the ancient limits of Seas and Continents. The study of fossils is destined to throw a great light upon the determination of the order of succession of the beds or strata, and of their relative age. The study of fossils may also enlightén questions of detail. Certain sorts of fish and of mollusea are known to be essentially belonging to rivers, and others to inhabit the seas. If the fossils of a stratum belong to the fresh-water species, we may legitimately conclude that such stratum has been deposited by river's or by lakes of fresh water. If, on the contrary, the fossil remains belong to the marine species, it may be presumed that the deposit in which they occur owes its origin to the waters of the sea.

In latter years fossils liave revealed remarkable facts concerning the state of the globe at various epoclis. Some anthors have sought to make use of them to define the shores and the configuration of the ancient seas; at least, we know that in the deep sea we find fewer molluses than near the coasts; the depth and absence of vegetation cause the greatest part of the species to avoid the centre of the seas; the shores, on the contrary, which furnish a more abundant nourishment, and the rocks near the surface, serve as shelter to a much larger number of individuals. The presence of numcrous fossils, and above all that of species which belong to the kinds essentially fluviatile, may then serve to indicate the shore of ancient estuaries, whilst rare fossils of species from the deep sea prove, on the contrary, that the strata have been deposited far from the coasts of seas at divers epochs. Thus it will be seen that geology would be but a barren study without some knowledge of the fossil remains of those beings who apparently first peopled the waters of the earth.

An inspection of the various strata in which fossil remains have been imbedded serves to prove that, in seneral, a constant order has existed in their formation. The sea, by which the entire earth appears to have been covered, having rested in eertain situations a sufficient length of time to collect particular substances, and to sustain the life of certain genera and species of animals, lias been afterwards replaced by another sea; which has collected other substanees, and nouri-hed other animals, whose remains are found in each stratum, and are generally limited to one formation, or, if reappearing in a successive stratum, much modified in size or structure. I have prepared here a diagram (page 3 ) which will give you an idea of the succession of epochs; each epoeh containing a sueeession of periods and formations, which, though often found to have been disturbed by some vast convulsive force, ean yet be retraeed to its natural order of succession and super-position.

The diagram (page 3) shews those formations whieh constitute the seeondary epoch, or, if described in ascending order, the eommencement of that vertebrate existence which left unequivocal evidence of its inhabiting the earth, by leaving the imprint of its footmarks, which, at one time, was all we knew of the extraordinary inhabitants of the New
Red Sandstone. This animal was called Chirotherium, from the hand-like shape of the foot-marks, until the mighty genius of Professor Owen placed the teeth and head before us, with such indisputable characters as united them to the footmarks, and thus, by induction, the whole animal (Labyrinthodon) was presented to us.

Next, in ascending succession, we have the Ich thyosaurus platyodon, tenuirostris, and communis, the Plesiosaurus dolichodeirus, as restored by Dean Conybeare, the Plesiosaurus macrocephalus and Hawkinsii, the latter named by Professor Owen after Mr. Thomas Hawkins, who with great enthusiasm cleared it from its matrix of lias, and who made the first great collection of fossils of the lias which were purchased by the trustees of the British Museum, where they now form the most striking features of the ional collection of fossils.

It next illustrates the upperportion of the lias, sometines known as the alum shale, so well developed at Whitby in which remains of the Teleosaurus have been frequently found. 'This animal will be recognised by its near resemblance to the crocodile of the Ganges called Gavial, or Garrial, as it should be ternied: to the casual observer the prineipal difference consists in its greater size. The next formation above the lias is the oolite, of which at prescnt that singular reptile, the Pterodactyle, represents the inhabitants, while one of the oolitic formations, called the Stonesfield slate, bears the great discovery of Buckland, the Megalosaurus, or the great lizard. 'This and the strata of the upper oolite bring us to the formation called the Wealden, which Professor Oren, in one of his elaborate descriptions of the British fossil reptiles, calls the inetropolis of the Dinosaurian order, which I have here represented by the best known and most typical species, the Hyl oosaurus or lizard of the weald, with its cxtraordinary dermal covering and long range of dorsal scutes, of which the bones were first discovered by the celebrated Dr. Mantell, whose persevering researches in Wealden formations first gave the idea to science of the former existence of the Inuanodon.

'These restorations of the Iguanodon I male from the measurements of the great Horsham specimen, as the largest is called, from its having been found and carefully preserved by $\mathrm{Hr}_{\mathrm{r}}$. Holmes, surgeon, at Horsham, who has bestowcd mucli care and attention on the development of the great fossils found in his neighbourhood, among which are the largest lnown specimens of the bones of the Iguanodon, having also the greater value of being found altogether, evidently belonging to one individual. These he kindly placed at my service for comparison with the better known Maidstone specimen now in the British Museum, which was so admirably extricated from its matrix and preserved by Mr. Bensted and Di. Mantell.

This Iguanodon was the animal the mould of which I converted into a salle ì manger, and in which I had the honour of receiving Professor Owen, Professor E. Forbes, and twenty of uny scientific friends to dinner on the last day of the year, 1853. 'This circumstance will bestillustrate the great size of these animals, the restoration of which has involved some of the greatest mechanical difcultics that can come within the sculptor's experience; and, if it will not be considered out of place, I will briefly state the process by which I have constructed these large models.

In the first week of September, 1852, I, entered upon nyy engagement with the Crystal Palaee Company to make the Mastodon, or any other models of the extinct animals that I might find most praeticable; such was the tenour of ny undertaking, and being deeply impressed with its inportant and perfectly novel character, without precedent of any kind, I found it necessary eariestly and carefully to study the elaborate descriptions of Marron Cuvier, but more partieularly the learned writings of our British Cuvier, Professor Oren. Here I found abundant material eolleeted together, stores of lnowledge from year's of labour, impressing me still more with the grave importance of attempting to present to the eye of the 


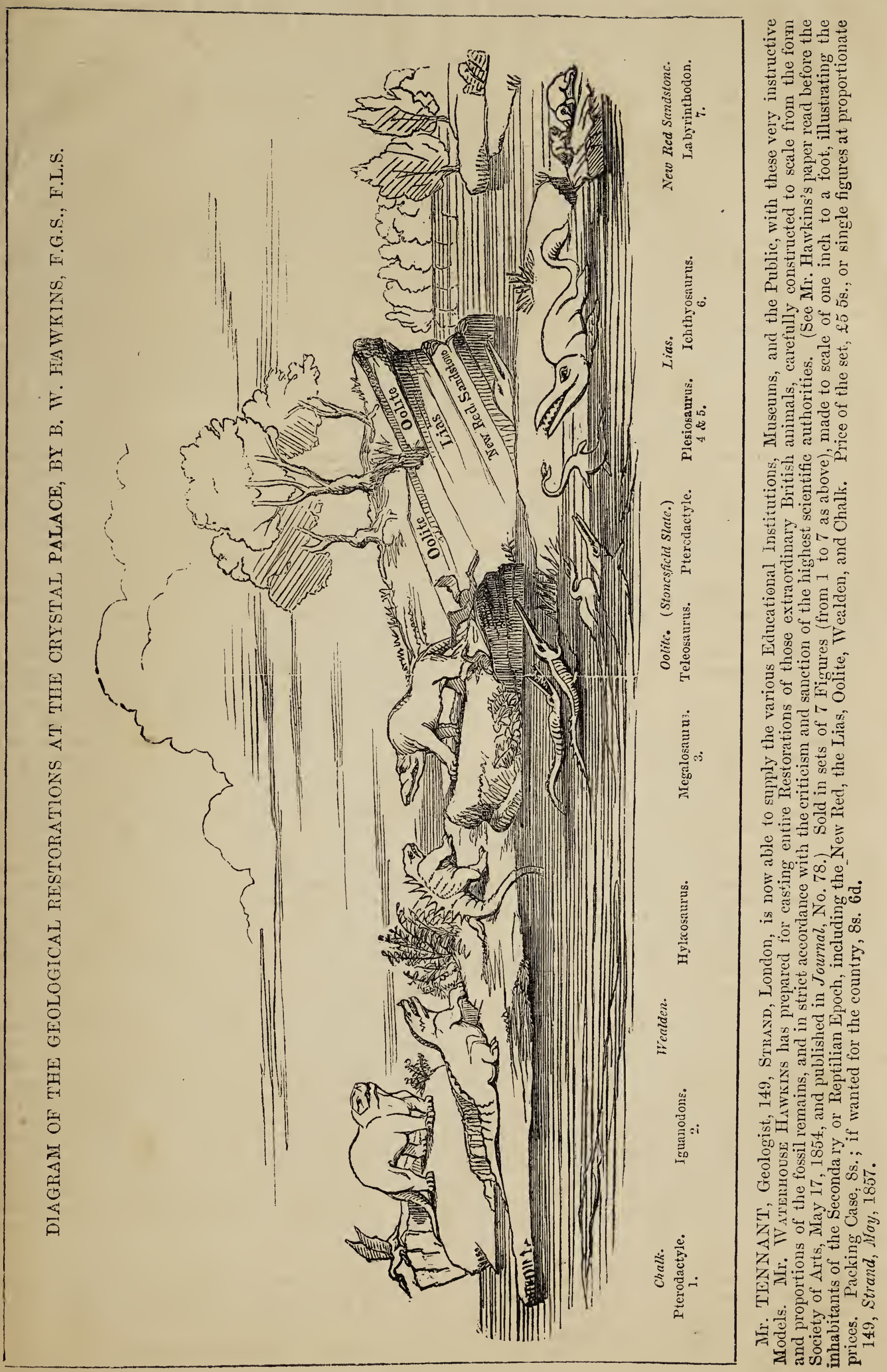


world at large a representation of the complete and living forms of those beings, the minutest portion of whose bones had occupied the study and research of oul most profound philosophers; by the careful study of their works, I qualified myself to make preliminary drawings, with careful measurements of the fossil bones in the Museum of the College of Surgeons, British Museum, and Geological Society; thus prepared I made my sketeh-models to scale, either a sixth or 12 th of the natural size, designing sueh attitudes as mylong acquaintanee with the recent and living forms of the animal kingdom enabled me to adapt to the extinct speeies I was endeavouring to restore. These sketch-models I submitted in all instances to the criticism of Professor Owen, who with his great knowledge and profound learning most liberally aided me in every difficulty. As in the first instanee it was by the light of his writings that I was enabled to interpret the fossils that I examined and compared, so it was by lis eriticism that I found myself guided and improved, his profound learning being brought to bear upon my exertions to realise the truth. His sanction and approbation obtained, I eaused the elay model to be built of the natural size by measurement from the sketch-model, and when it approximated to the form, I with my own hand in all instances secured the anatomical details and the eharacteristics of its nature.

Some of these models contained 30 tons of elay, which had to be supported on four legs, as their natural history. eharacteristics would not allow of my having reeourse to any of the expedients for support allowed to seulptors in an ordinary case. I conld have no trees, nor roeks, nor foliage to support these great bodies, which to be natural, must be built fairly on their four legs. In the instanee of the Iguanodon, it is not less than building a house upon four columns, as the quantities of material of whieh the standing Iguanodon is eomposed, consist of 4 iron eolumns 9 feet long by 7 inches dianeter,

600 brieks,

650 2-ineh half-round drain-tiles,

.00 plain tiles,

38 casks of eement,

90 casks of broken stone,

making a total of 650 bushels of artificial stone.

These, with 100 feet of iron hooping and 20 feet of cube inch bar, constitute the bones, sinews, and muscles of this large model, the largest of which there is any record of a casting being made.

I have only to add that my earnest anxiety to render these restorations truthful and trustworthy lessons has made me seek diligently for the truth and the reward of Professor Owen's sanction and approval, which I have been so fortunate as to obtain, and my next sineere wish is that, thus sanctioned, they may, in conjunetion with the visual lessons in every department of art, so establish the efficiency and facilities of visual education as to prove one of many sources of profit to the shareholders of the Crystal Palace Company.

\section{DISCUSSION,}

The Dean of Hereford said he had listened, as he was sure every one present must have done, with great interest to the admirable paper of $\mathrm{Mr}$. Waterhouse Hawkins, who lad brought before them many animals to most of them probably unknown, and so perhaps they would have remained, had they not been represented in this way. He should be glad to see those models multiplied at a price
whieh would enable them to be introduced into village and ordinary schools, as every one could not visit the Crystal Palace, and he therefore hoped that specimen. like those before them might be rendered attaina le by those in remote and secluded districts, who would " pt have the advantage of witnessing the splendid and gig ontic illustrations of the extinct ereation of the early ages of the world which would be there exhibited. He would also express a hope that specimens like those might be introduced in eonnection with the approaching Educational Exhibition of the Society, as it would be of great importance in an educational point of view, that sehoolmasters and teachers of the young might thereby have an opportunity of seeing what had been done, and what they might do for themselves, if they could purchase those models at a moderate price. It would be doing for the extinct world what they had not done for the existing one, because, in many of the rural districts the young were taught the nature and liabits of elephants, lions, and tigers, and yet had never seen either a living specimen or even an accurate nodel of those animals. He should now be glad to hear the observations of any gentleman upon the subjeet of the paper which had been brought before them that evening, and as he saw Professor I'ennant present, perhaps he would favour the meeting with a few remarks upon a matter with which he was so intimately aequainted.

Mr. Tennant observed, that he had but little to say after what had been stated in the paper, beeause to go through the various models exhibited in detail would occupy several hours. Having had on more than one occasion an opportunity of witnessing the process of building up the models of these monster animals, it was astonishing to see the skill with which Mr. Hawkins built up, pieee by pieee, those gigantic and extraordinary representations. When they looked at the bories on the table, and eompared them with the thigh-bones of the largest animals with which they were now acquainted, they were taken by surprise, and it required the learning and erudition of a Conybeare, Buckland, or Owen to re-create these extinct animals from detaehed fossil remains. Most persons present had, no doubt, seen the fossil Ichthyosaurus in the British Museum, which was 22 feet in length; but these beautitul models earried the mind baek in tine to the periods when these ereatures were living in the seas which washed our own coasts. We are now standing upon an aneient sea-bottom, and the race of animals which then existed had been brought to light, for the most part, only in a fragmentary state, like the fossil remains upon the table. Owing to the facilities which now existed of visiting all parts of the country, and eollecting fossils on the spot, and afterwards going to the Crystai Palace, and seeing the restoration of the animals, a more accurate knowledge of those wonders of creation was obtained than eould be eommunieated by lengthened seientifie details. They were not looking at the anatomical strueture only, but they saw them elothed as it were in their original armour, many of them with gigantie scales, and formidable spines.

Mr. Harry Chester said - That a great service would be rendered to edneation by multiplying the casts and illustrations before them. ******* No doubt much important serviee might be rendered if these models were put into a form in whieh they would be easily attainable by those engaged in education. He thought it would be highly desirable that a stall should be occupied by these casts at the approaching Educational Exhibition of the Society, and it would be of great service if Mr. Hawkins would, at a convenient period, deliver a leeture or read a paper upon them, for the benefit of the large number of schoolmasters and schoolmistresses who, he hoped, would be attracted to that exhibition.

An extensive assortment of Minerals, Shells, and Fossils, together with all the recent Works relating to Mineralogr, Geologr, Conchomogr, and Chenistri, Geological Maps, Hammers, Blowpipes, Acid Bottles, \&c.,
can be supplied by 



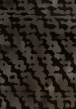

